\title{
Reclamation of Mercury from Used Silver Oxide Watch Batteries
}

\author{
Natarajan Sathaiyan \\ Electro Hydro Metallurgy Division, CSIR-Central Electro Chemical Research Institute, Karaikudi, India \\ Email: enes@rediffmail.com
}

Received November 13, 2013; revised December 13, 2013; accepted December 20, 2013

Copyright (c) 2014 Natarajan Sathaiyan. This is an open access article distributed under the Creative Commons Attribution License, which permits unrestricted use, distribution, and reproduction in any medium, provided the original work is properly cited. In accordance of the Creative Commons Attribution License all Copyrights (C) 2014 are reserved for SCIRP and the owner of the intellectual property Natarajan Sathaiyan. All Copyright (C) 2014 are guarded by law and by SCIRP as a guardian.

\section{ABSTRACT}

This paper deals with the reclamation of mercury from the used silver oxide quartz wristwatch batteries employing leaching-cementation technique. The used batteries are first crushed to liberate the encapsulated active material from the case which is leached in nitric acid to bring all metal contents into solution. After the removal of silver in the solution as silver chloride by precipitation, the mercury which is present as $\mathbf{H g}^{2+}$ in the solution has been reclaimed through cementation with zinc dust. Various effects like zinc sheet and dust, zinc quantity, pH of the solution, duration and temperature have been carried out to standardise the conditions for maximum mercury reclamation. At a temperature of $45^{\circ} \mathrm{C}$ and at $3.9 \mathrm{pH}, 92.3 \%$ of mercury was recovered using $74 \mu \mathrm{m}$ size zinc dust with purity greater than $99.78 \%$ and the same is characterized by XRF and the results are discussed.

\section{KEYWORDS}

\section{Used Silver Oxide-Zinc Watch Batteries; Leaching; Zinc Dust; Cementation; Mercury}

\section{Introduction}

Even though mercury is a highly toxic metal, it has many applications like: manufacture of chemicals, industrial instruments, dental amalgams, fluorescent light bulbs, switches, control equipments, hospital equipments, batteries etc.

Tablets like silver oxide-zinc batteries are mainly used in quartz wristwatches in addition to calculators, cameras, hearing aids [1]. After their service life of about 2 years, they become a waste leading to environmental problems. The recovery of precious metal, viz., silver from these waste silver oxide button cells has already been reported [2]. Whilst the exact chemical makeup varies from type to type, most batteries contain heavy metals which are the main cause for the environmental concern. These batteries must not be incinerated, buried or thrown away in general trash. Proper disposal of the scrap silver oxide batteries used in most of today's watches is mandated by environmental regulation. When disposed off incorrectly, the heavy metals of the used batteries may leak into the ground when the battery casing corrodes. Even though batteries account for less than $0.001 \%$ of domestic waste, it is utmost important to recover their metallic values since they possess precious as well as toxic metals. If the metal values are not recovered from them, this can contribute to soil and water pollution and endanger wild life. Even $1 \mathrm{~g}$ of mercury from wastes is enough to contaminate a lake with a surface area of about 20 acres to the degree that fish would be unsafe to eat. Mercury is no longer being used in the manufacture of non-rechargeable batteries except button cells where it is a functional component for preventing the anode corrosion.

Wristwatch manufacturing industries also meet the problem of disposal of these primary batteries when they are either not sold or used due to long duration. Worldwide 15 billion primary batteries are thrown away every year, all of which end up in landfill sites. Currently only a very small percentage of about $2 \%$ of consumer disposable batteries are recycled.

Even though quartz watch battery constitutes only 3\% of the battery industry, in a year, about 100 million units of used watch batteries are generated in India possessing mercury content of about 0.05 to 0.1 ton. Different sizes of watch batteries like SR1120SW, SR927SW, SR920- 
SW, SR721SW, SR626SW, SR621SW, and SR521SW are available in watch shops for different size of wristwatches. The model SR721SW watch battery (Maxell, Hitachi Maxell Ltd., Japan) has a diameter of $7.9 \mathrm{~mm}$, height of $2.1 \mathrm{~mm}$ with a weight of $0.417 \mathrm{~g}$. The nominal voltage of the cell is $1.55 \mathrm{~V}$. In the silver oxide-zinc watch battery, the anode (positive) consists of activated zinc with a heavy metal as additive like mercury to avoid corrosion, while the cathode (negative) consists of sintered fine silver oxide powder $\left(\mathrm{Ag}_{2} \mathrm{O}\right)$. Typical watch battery composition is provided in $[3,4]$. The electrode reactions after the full discharge of the battery are given [2].

A variety of battery collection systems are available. The watch shops, where the exhausted battery is replaced by new battery, preserve the used batteries for selling to private parties who employ crude methods for the metals recovery leading to environmental pollution besides endangering the workers health. Most recycling systems are designed for a single battery chemistry. However all battery types may be collected together. Sorting is then required. A number of sorting systems have been developed based on various combinations of physical and chemical separations. The Dutch Research Institute (TNO) has developed a system in which batteries are sorted on the basis of X-ray pattern recognition capable of sorting at least $1 \mathrm{t} \cdot \mathrm{h}^{-1}$. The Clean Japan Center system sorts batteries according to size, shape and weight using a vibratory magnetic separator which can sort up to $43 \mathrm{t} \cdot \mathrm{h}^{-1}$ [5]. Titalise S.A. of Switzerland based their TRI-MAG system on electromagnetic identification of metallic battery constituents. It is said to be able to sort at least $1 \mathrm{t} \cdot \mathrm{h}^{-1}$ [6]. At present hand sorting is often said to be the most efficient and reliable method, even though problems arise when batteries are leaking or damaged. Quick sorting of spent silver oxide batteries is possible through their sizes.

The Mercury Refining Company accepts and sorts out most domestic batteries by hand. All mercuric oxide and silver oxide batteries are retorted for mercury reclamation [7]. The Alexander Battery Manufacturing in Mason City, IA, USA recovers mercury from used batteries through distillation [8].

Mercury removal from waste sewage sludge is reported [9] employing phosphoric acid as the extractant but this requires an additional step for the elution of mercury from the acid and the purification required for reusing the phosphoric acid. Precipitation method is adopted in [10] for removing lead metal from industrial effluents. Spent silver oxide batteries are disassembled into a zinc amalgam-based anode part and a silver oxide-based cathode part. Anode part and turnings were roasted for $2 \mathrm{~h}$ at $\sim 650^{\circ} \mathrm{C}$ to recover mercury, steel-Ni scrap and zinc. The cathode ingredient was reduced to recycle silver [11].
These reported methods have many disadvantages like: 1) emission of toxic gases like mercury endangering the environment and workers health, 2) high power consumption, 3) involving costly instruments, 4) high cost, 5) occupying large space, 6 ) multi-steps recovery with safe disposal of sludges etc.

In order to avoid these drawbacks, a leaching-cementation route is adopted in this investigation on the reclamation of mercury from the used silver oxide-zinc button cells. In this research paper, hand sorting is adopted to collect the used silver oxide watch batteries.

Cementation is a very complex process and it depends on the concentration of metal ion in solution, agitation of solution, $\mathrm{pH}$, temperature and the presence of sacrificial metal.

If a metal baser to mercury in the electrochemical series of the elements is placed in a solution containing mercuric ion, an oxidation/reduction couple is formed with mercury being reduced to the elemental state as shown by Equation (1).

$$
\mathrm{Zn}^{0}+\mathrm{Hg}^{2+} \rightarrow \mathrm{Zn}^{2+}+\mathrm{Hg}^{0}
$$

In the cementation route, the positive metals are easily reclaimed in a single-step and hence, this method is preferred over other methods like precipitation resulting in the formation of hazardous sludges, which require further treatments for their safe disposal. Even though, sacrificial metal is used for the cementation with its dissolution, attention is focused on selecting zinc metal which already exists in the leached solution. The zinc metal is economically suitable and chemically efficient.

Mercury is not produced in India and she depends totally on import for its various industrial applications.

The present investigation deals with the reclamation of mercury by cementation in nitrate medium since nitric acid is used as the leachant for the leaching of the active mass collected from the used silver oxide button cells.

\section{Experimental}

\subsection{Silver Oxide-Zinc Watch Battery}

The used silver oxide-zinc battery's cross-sectional view is given [2]. Table 1 shows the composition of used silver oxide-zinc battery. Mercury is present as additive to avoid corrosion of anode zinc and bulging of steel case besides giving a better cell-life.

\subsection{Collection of Active Material from Used Batteries}

Commercially available used silver oxide-zinc watch batteries were employed in this study. The cells were crushed mechanically and the encapsulated active material was collected carefully with minimum loss. The cases and lids were rejected. 


\subsection{Flow Diagram for Mercury Reclamation}

Figure 1 gives the flow diagram for the reclamation of mercury from used silver oxide-zinc watch batteries. The unit operations adopted in this investigation is vividly given in the flow diagram. The leaching of active mass is carried out with $200 \mathrm{~g} \cdot \mathrm{dm}^{-3}$ nitric acid at $60^{\circ} \mathrm{C}$ with a duration of 30 minutes for maximum leaching of active mass. The silver present in the leach solution is selectively removed as silver chloride by adding stoichiometric excess of $25 \%$ sodium chloride solution and filtered to remove the silver chloride precipitate. The filtrate is subjected to cementation with zinc powder under various conditions for the maximum reclamation of mercury.

Table 1. Composition of used silver oxide-zinc button battery.

\begin{tabular}{cc}
\hline Components & Weight (\%) \\
\hline Silver & 29.7 \\
Zinc & 9.8 \\
Mercury & 0.7 \\
Steel case & 43.2 \\
NaOH & 6.9 \\
Plastic/Paper & 6.7 \\
Water & 2.4 \\
Balance & 0.6 \\
\hline
\end{tabular}

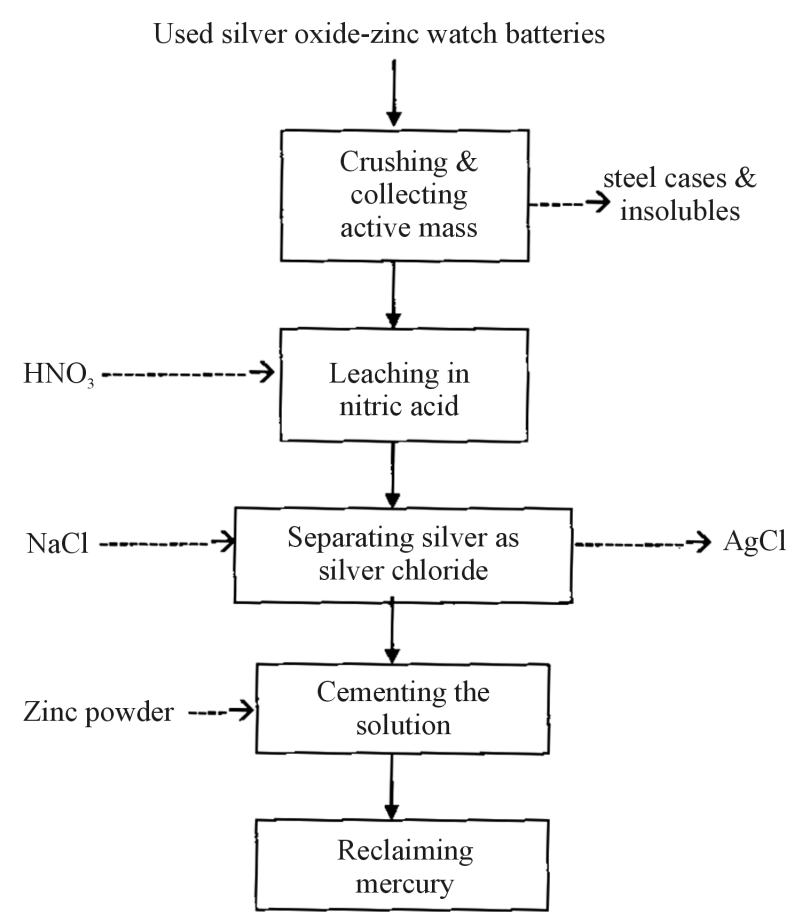

Figure 1. Flow diagram for reclamation of mercury from used silver oxide-zinc watch batteries.

\subsection{Leaching, Separation and Analysis of Mercury in Used Silver Oxide Button Cells}

$100.436 \mathrm{~g}$ of active material liberated from $200.56 \mathrm{~g}$ of used batteries was subjected to leaching with $200 \mathrm{~g} \cdot \mathrm{dm}^{-3}$ nitric acid in a closed glass reactor of $1000 \mathrm{ml}$ capacity. The solution was stirred continuously with a variable speed mechanical stirrer at 600 RPM and the temperature was maintained at $60^{\circ} \mathrm{C}$ for 30 minutes at the solid: liquid ratio of 1:3.5 during the leaching. The mercury present is oxidised and the reactions are given in Equations (2), (3).

$$
\begin{aligned}
& \mathrm{Hg}^{0} \rightarrow \mathrm{Hg}^{1+}+1 \mathrm{e}^{-} \\
& \mathrm{Hg}^{1+} \rightarrow \mathrm{Hg}^{2+}+1 \mathrm{e}^{-}
\end{aligned}
$$

The entire silver in the leach solution was removed through precipitation as silver chloride employing 25\% stoichiometric excess of sodium chloride solution leaving mercury and zinc contents only in the leached solution which was made up to $500 \mathrm{ml}$ in a standard volumetric flask. The concentration of mercury in the leached solution was determined by atomic absorption spectrophotometer and it is $2.05 \mathrm{~g} \cdot \mathrm{dm}^{-3}$.

\subsection{Mercury Recovery by Cementation and Its Purification}

The leached solution was subjected to cementation with zinc sheet and powders (Fischer, purity: 99.5\%, $74 \mu \mathrm{m}$ and $44 \mu \mathrm{m}$ sizes). Zinc powders were used without any prior cleaning. The cementation was carried out in a 3 mouth flat bottom glass reactor of $500 \mathrm{ml}$ capacity. The contents were agitated with stirring provided by a variable speed mechanical stirrer at 600 RPM and the temperature was maintained at $30^{\circ} \mathrm{C}-60^{\circ} \mathrm{C}$ with a duration of 5 - $45 \mathrm{~min}$ in the $\mathrm{pH}$ range of 1.0 - 5.5 with zinc ranging from 100 - $1000 \mathrm{wt}$ (\%) stoichiometric excess. The $\mathrm{pH}$ of the solution was controlled by the addition of weak alkali solution like sodium carbonate and measured by employing a $3 \frac{1}{2}$ digital $\mathrm{pH}$ meter. Uniform temperature was provided by hot plate with provision for temperature control. After the cementation was over, the solution was filtered to collect the mercury. It was cleaned 4 - 5 times with AR grade $10 \%$ nitric acid, then washed with distilled water to remove even trace amount of acid and dried. It was then allowed to pass through a filter paper slowly which was pin holed at the tip of the filter funnel and purified mercury was collected.

\subsection{Collection of Active Material from Used Batteries}

The mercury metal reclaimed was analysed volumetrically for its purity [12]. X-ray fluorescence method was used to characterise the mercury metal obtained before and after its purification. 


\section{Results and Discussion}

\subsection{Effect of Zinc Sheet and Powders}

The effect of zinc sheet and particles on reclamation of mercury is shown in Figure 2. Generally, reaction rate rises with increase in the surface area.

In the cementation of mercury from the leached solution of the active mass of the used silver oxide-zinc button cells, the formation of mercury is directly related to the surface area of the reducing agent zinc. From the figure one can observe that the low reclamation of mercury (28.9\%) by the electrolytic zinc sheet may be due to the less surface area and high recovery of mercury with zinc powders is attributed to the large surface area. Among the zinc dusts, the $74 \mu \mathrm{m}$ zinc particle shows the highest value of reclamation of mercury (71.7\%) than $44 \mu \mathrm{m}$ zinc dust with $61.4 \%$ of recovery. The lower value may be due to the chemical attack on the fine zinc powder. Hence all the subsequent experiments were carried out employing $74 \mu \mathrm{m}$ size zinc dust.

\subsection{Effect of Quantity of Zinc Powder}

The effect of quantity of zinc powder with stoichiometric excess wt (\%) ranging from $100 \%$ to $1000 \%$ on the cementation of mercury is given in Figure 3. This figure clearly reveals that exact stoichiometric quantity of zinc powder is not enough for the complete cementation, which may be due to the reduction of hydrogen ions in the solution. With increase in stoichiometric excess, the mercury recovery $\%$ also increases $[13,14]$ and the rise is only marginal above $700 \mathrm{wt}(\%)$.

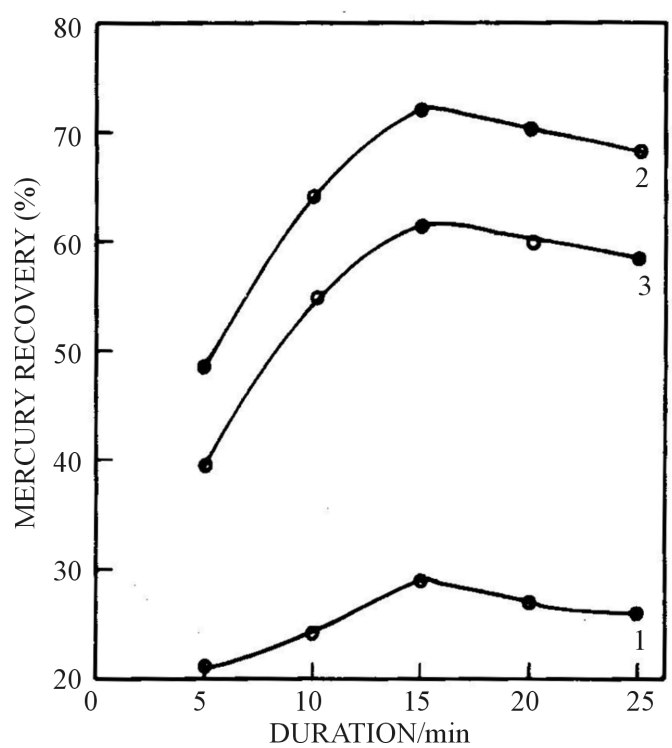

Figure 2. Effect of zinc sheet and powders on mercury reclamation from $2.05 \mathrm{~g}$ mercury leach solution at $4.2 \mathrm{pH}$, $40^{\circ} \mathrm{C}, 15 \mathrm{~min}, 400 \mathrm{wt} \%$ excess zinc: (1) zinc sheet, (2) $74 \mu \mathrm{m}$ size zinc powder and (3) $44 \mu \mathrm{m}$ size zinc powder.

\subsection{Effect of pH}

Figure 4 gives the effect of $\mathrm{pH}$ ranging from 1 to 5.5 on cementation of mercury carried out under identical conditions. At low $\mathrm{pH}$, the cementation is found to be low due to higher chemical dissolution of zinc. With increase in $\mathrm{pH}$, the mercury recovery \% increases, but above 3.9 there is decrease in recovery due to the hydroxide precipitation as per the following Equation (4).

$$
\mathrm{Zn}^{2+}+2(\mathrm{OH})^{1-} \rightarrow \mathrm{Zn}(\mathrm{OH})_{2}
$$

Hence, the optimum $\mathrm{pH}$ value is kept at 3.9.

\subsection{Effect of Duration}

The effect of duration on cementation of mercury is presented in Figure 5. The reclamation of mercury is found to rise with increase in duration up to 30 minutes under the specified experimental conditions and above $30 \mathrm{~min}$ the reclamation starts decreasing which may be attributed to the redissolution of mercury formed. Regarding Figure 2, the mercury recovery was the maximum at $15 \mathrm{~min}$. This anomaly is attributed to the change in experimental conditions.

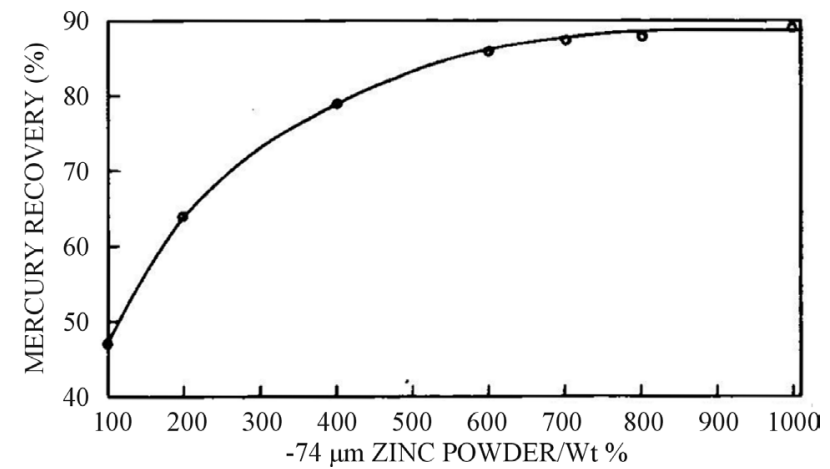

Figure 3. Effect of quantity of $74 \mu \mathrm{m}$ size zinc powder on mercury reclamation from $2.05 \mathrm{~g}$ mercury leach solution at $4.2 \mathrm{pH}, 40^{\circ} \mathrm{C}$ and $30 \mathrm{~min}$.

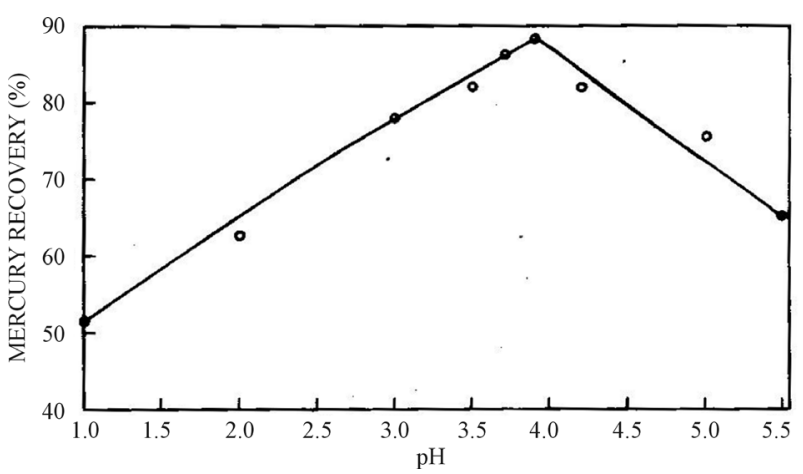

Figure 4. Effect of pH on cementation of mercury from 2.05 g mercury leach solution at $40^{\circ} \mathrm{C}, 30 \mathrm{~min}$ and $700 \mathrm{wt} \%$ of 74 $\mu \mathrm{m}$ size zinc powder. 


\subsection{Effect of Temperature}

The temperature effect on mercury reclamation is shown in Figure 6. From this figure one can observe rise in the percentage of mercury reclamation with increase in temperature and the rise is negligible after $45^{\circ} \mathrm{C}$.

\subsection{Characterisation of Mercury}

The purity of $4.63 \mathrm{~g}$ of mercury produced by cementation was analysed volumetrically and is $>99 \%$. Both nonpurified and purified mercury were characterised by Xray fluorescence (XRF). The purity data and XRF graph pattern of mercury are given in Table 2 and Figure 7

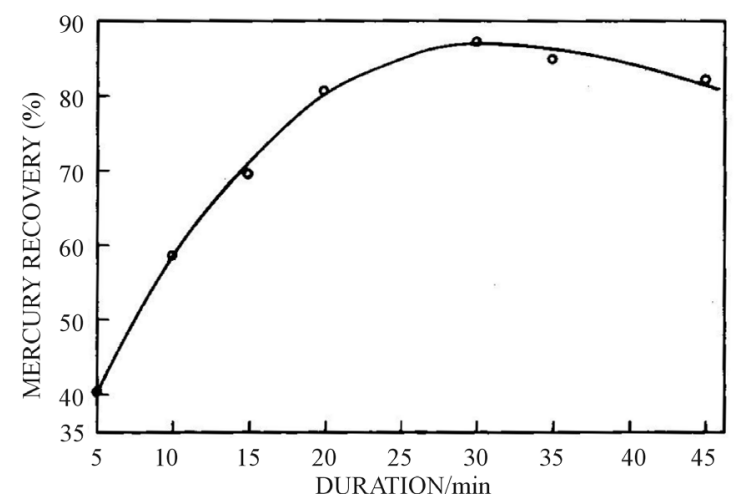

Figure 5. Effect of duration on mercury cementation from $2.05 \mathrm{~g}$ mercury leach solution at $40^{\circ} \mathrm{C}, 3.9 \mathrm{pH}$ and $700 \mathrm{wt} \%$ 74 $\mathrm{m}$ size zinc powder.

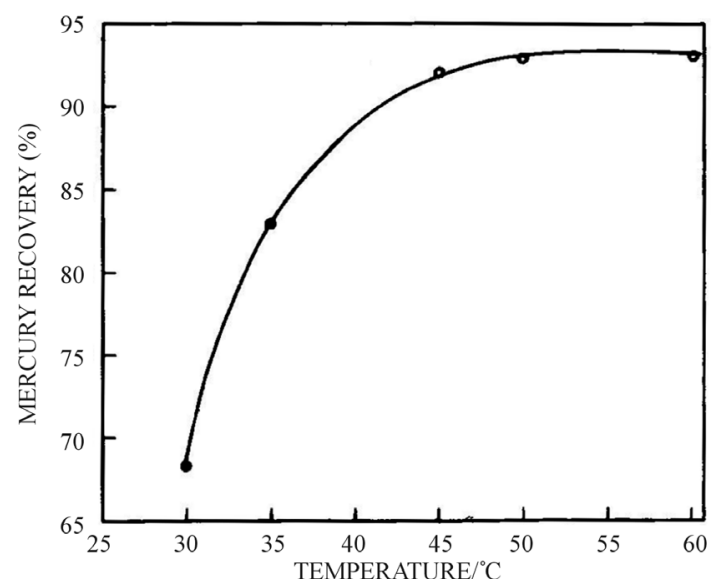

Figure 6. Effect of temperature on reclamation of mercury from $2.05 \mathrm{~g}$ mercury leach solution at $3.9 \mathrm{pH}, 30 \mathrm{~min}$ and $700 \mathrm{wt} \%$ of $74 \mathrm{\mu m}$ size zinc powder.

Table 2. Purity level of mercury by XRF.

\begin{tabular}{ccc}
\hline \multirow{2}{*}{ Element } & \multicolumn{2}{c}{ Composition (\%) } \\
\cline { 2 - 3 } & Not purified & Purified \\
\hline Mercury & 99.78 & 99.90 \\
Zinc & 0.22 & 0.09 \\
\hline
\end{tabular}

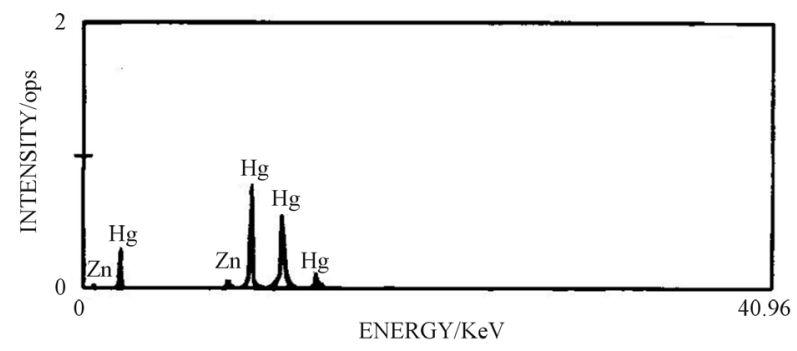

(a)

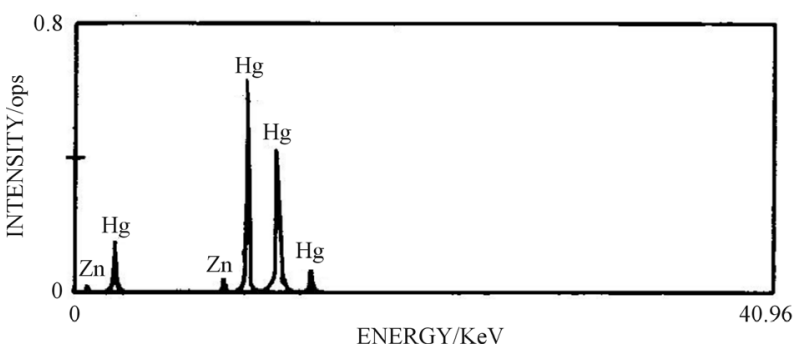

(b)

Figure 7. XRF patterns of (a) reclaimed mercury and (b) purified mercury.

respectively.

From the table it is observed that the purity of the mercury metal produced is $99.78 \%$ with trace of zinc impurity. The tall peaks observed in Figure 7(a) show the presence of mercury, while tiny peaks observed in this figure are due to the presence of the cementing reagent zinc in the non purified sample. Through the cleaning step, the purity of the mercury metal is increased to $99.90 \%$ with decrease in zinc level to $0.09 \%$ which is clearly revealed in Figure 7(b).

Since the weight (\%) of steel case of used silver oxide quartz watch batteries is almost half the weight of the battery, it is better to liberate the active mass for the mercury reclamation by breaking the battery case before acid leaching. Even though one might think that it will be a time consuming process, but the consumption of acid could be reduced considerably, thereby eliminating the iron disposal problem besides the reclamation of high pure mercury product. The rejected steel cases may be utilised by the steel industries for remelting.

\section{Conclusion}

Cementation could advantageously be adopted for the reclamation of mercury from the used silver oxide quartz watch batteries. Mercury reclamation from $3.9 \mathrm{pH}$ leach solution after the separation of silver content is high (92.3\%) with $700 \mathrm{wt}(\%)$ stoichiometric excess of $74 \mu \mathrm{m}$ size zinc dust at $45^{\circ} \mathrm{C}$. The purity of the mercury product is $99.78 \%$ and the purity level is increased to $99.9 \%$ by acid treatment which is vividly exhibited in the XRF pattern. The purified mercury product can be used by the user industries. 


\section{Acknowledgements}

The author conveys his sincere thanks to Sri. V. Nandakumar, Head, EHM Division, CECRI, Karaikudi-6 for his interest in this work, Dr. J. Prabhakar Rethinaraj, retired Scientist of EHM Division, CECRI, Karaikudi-630 006 for his critical suggestions with valuable guidance and to Dr. Vijayamohanan K Pillai, Director, CSIR-Central Electro Chemical Research Institute (CECRI), Karaikudi-630006, India, for his kind permission to publish this article.

\section{REFERENCES}

[1] C. L. Mantell, "Batteries and Energy Systems," Mc GrawHill Book Co., New York, 1970, pp. 90-91.

[2] N. Sathaiyan, V. Nandakumar and P. Ramachandran, "Hydrometallurgical Recovery of Silver from Waste Silver Oxide Button Cells,” Journal of Power Sources, Vol. 161, 2006, pp. 1463-1468. http://dx.doi.org/10.1016/j.jpowsour.2006.06.011

[3] C. J. Beyke, "Houshold Battery Recycling in the United States,” G. W. Warren, Ed., EPD Congress, The Minerals, Metals \& Materials Society, 1995, pp. 491-502.

[4] J. Frenay and S. Feron, "Domestic Battery Recycling in Western Europe,” Proceedings of Second International Symposium on Recycling of Metals and Engineered Materials, Vol. 2, 1990, pp. 639-647.

[5] N. Reutlinger and D. De Grassi, "Household Battery Recycling: Numerous Obstacles, Few Solutions,” Resource
Recycling, Vol. 5, No. 4, 1991, pp. 24-29.

[6] J. P. Wiaux, A. Indaco and A. Lazouni, "Collecting, Sorting and Recycling Spent Batteries,” Geneva, 1993.

[7] B. Ames, "Private Communication," Alexander Batteries, 1994, unpublished.

[8] T. Andolino, "Private Communication,” Alexander Batteries, 1994, unpublished.

[9] S. Yoshizaki and T. Tomida, "Principle and Process of Heavy Metal Removal from Sewage Sludge,” Environmental Science and Technology, Vol. 34, No. 8, 2000, pp. 1572-1575. http://dx.doi.org/10.1021/es990979s

[10] P. Kamaraj, S. Jacob and D. Srinivasan, "Removal of Heavy Metals from Waste Water by Sulphide Precipitation Technique,” Bulletin of Electrochemistry, Vol. 5, No. 8, 1989, pp. 572-574.

[11] T. Uenishi and I. Junnosuke, "Metals Recovery from Spent Silver Oxide Batteries,” Japan Patent No. 6036827, 1985.

[12] H. A. Flaschka, "EDTA Titrations," Pergamon Press, Oxford, 1964, p. 71.

[13] A. L. Anacleto and J. R. Carvalho, "Mercury Cementation from Chloride Solutions Using Iron, Zinc and Aluminium,” Minerals Engineering, Vol. 9, No. 4, 1996, pp. 385-397. http://dx.doi.org/10.1016/0892-6875(96)00025-8

[14] Y. Ku, M.-H. Wu and Y.-S. Shen, "Mercury Removal from Aqueous Solutions by Zinc Cementation," Waste Management, Vol. 22, No. 7, 2002, pp. 721-726. http://dx.doi.org/10.1016/S0956-053X(02)00053-3 